Актуальні проблеми розвитку готельно-ресторанного бізнесу

Actual problems of the hotel and restaurant business development

UDC 640.4:659.126]:316.346.32-053.81"18/35”

DOI: $10.31866 / 2616-7468.4 .1 .2021 .234827$

\section{THE ROLE OF MILLENNIALS IN THE FORMATION OF THE HOTEL AND RESTAURANT BUSINESS BRAND}

Oksana Polinkevych, Doctor of Economics,

Lutsk National Technical University, Lutsk, Ukraine

kravomp@gmail.com

https://orcid.org/0000-0001-6924-7296

(C) Polinkevych O., 2021

The topicality. In the context of the COVID-19 pandemic, the latest technologies to stimulate business development are becoming important. The source of change is millennials, which determine the prospects for development and contribute to the formation of competitiveness in the market. The purpose of the article is to determine the role of millennials in the formation of the hotel and restaurant business brand in the conditions of COVID-19. Research methods. The study used general scientific methods: analysis, abstraction, induction, deduction, synthesis, inference, generalization, comparison. Research results. The peculiarities of the concept of "millennials" have been defined. It has been established that millennials are young people aged 18-35 who have a positive impact on the development of the hotel and restaurant business and are generators of change. An expert assessment of the impact of millennials on the hotel and restaurant business was conducted. It identifies the main technologies preferred by millennials by gender and age group. The scheme of formation of the brand model by millennials in the conditions of COVID-19 has been developed. Conclusions and discussions. It is determined that millennials are the main driving force of strategic changes in the hotel and restaurant business and contribute to the development and competitiveness of organizations.

Keywords: hotel and restaurant business, millennials, COVID-19, scheme, development, brand, branding.

\title{
The topicality of the problem
}

The problem formulation. In the context of the COVID-19 pandemic, the latest technologies to stimulate business development, including marketing, production, information, etc., are becoming important. This period is characterized by a reduction in travel by $22 \%$, a decrease in profits to $57 \%$, the suspension of regular air services between countries (Kasum et al., 2020, p. 4). In 2020, Ukraine's GDP is predicted to fall to $7.7 \%$, with the unemployment rate reaching $10 \%$. This value is $3.7 \%$ less than the projected value of the fall in GDP at the predicted unemployment rate (State Statistics Service of Ukraine, 2021). According to the report of the IMF, the World Bank, the OECD, both Ukraine and the rest of the world will be able to restore their economic situation in the second half of 2021, but it is impossible to fully compensate for the negative effects caused in 2020 (International Monetary Fund, 2020). This is confirmed by the fact that the economy has already begun to recover from the pandemic, as the decline in GDP was much smaller than expected. It is projected that the international economy will be able to reach the state of 2020 only in 2022. Three main rating agencies also gave their assessment of the situation in Ukraine: Standard and Poor's and Fitch ranked Ukraine in category B (high speculative level). According to Moody's, Ukraine's credit rating has a Caa1 rating (significant risk). However, on April 23, 2020, Fitch changed the previous 
rating, lowering it to B from BB (speculative level) with a forecast of "stable". A report by the United Nations World Tourism Organization (STR, ForwardKeys, May 6, 2020) states that leading banks and economists are actively emphasizing the seriousness of the negative effects of the COVID-19 pandemic on the world economy and its reduction (Kasum et al., 2020, p. 7-8). State study of the problem. N. Trishkina (2017) dealt with branding issues, which determined that the brand plays a decisive role in the hotel business. The author suggested ways to form a system of brand-oriented integrated marketing communications of hotel enterprises. The value of the hotel brand is determined by the customer's willingness to buy hotel services at a higher price in the presence of similar hotel services on the market of other brands. R. Genc (Genc, 2010) identified the benefits of co-branding management, including: investment in branding, increasing the average daily hotel price, increasing hotel occupancy, increasing net income and profits. Cobranding affects how a company or service / product are perceived by customers. It forms a diversified customer base, increases its visibility, sense of security, and facilitates decision-making.

Approaches to the hotel and restaurant business development have been considered by a number of scientists. In particular, V. Glonti, V. Trinchuk, I. Khovrak, G. Mokhonko, M. Shkrobot and L. Manvelidze (Glonti et al., 2020) studied the need to introduce social responsibility, O. Polinkevych and R. Kaminsky (Polinkevych \& Kamiński, 2018) - marketing technologies and image of enterprises, O. Danylenko, L. Zotsenko and M. Bratitsel (2019) - digital technologies development in the restaurant business (FOOODTECH), Z. Shatska and A. Shevel (2020) - organization of the hotel industry in a pandemic COVID-19, M. Zubareva (2015) - tools to promote the hotel on social networks, M. Manov and O. Karolop (2018) - hotel and restaurant business development in times of crisis, M. Lyashuk and I. Yerko (2020) current trends have been identified in the hotel and restaurant business of Dubna recreational area, T. Verevka (2019) - the role of digital innovations in hospitality and adaptation of the enterprise to the possibilities of the digital revolution or to the conceptual breakthrough that arises from Industry 4.0. Unresolved issues. However, these works did not define the role of millennials in shaping the brand of the hotel and restaurant business.

\section{Purpose and research methods}

The purpose of the article is to determine the role of millennials in the formation of the hotel and restaurant business brand in the conditions of COVID-19. To achieve this goal, the following tasks were solved: defining the essence of the concept of "millennial", developing a brand model of the hotel and restaurant business, taking into account the preferences of millennials.

The methodological basis of the research is to study the impact of millennials on the hotel and restaurant businesses development through the use of brand management.

Research methods: analysis, abstraction, induction, deduction, synthesis, inference, generalization, comparison.

The object of research is the processes of branding formation of hotel and restaurant business taking into account the preferences of millennials.

The subject of research is the branding of the hotel and restaurant business. 
Актуальні проблеми розвитку готельно-ресторанного бізнесу Actual problems of the hotel and restaurant business development

The scientific novelty of the study is to substantiate the peculiarities of the influence of millennials on the formation of the brand of hotel and restaurant businesses in order to ensure their competitiveness.

The information base of the study is monographs and scientific articles of domestic scientists, domestic and foreign statistics.

\section{Research results}

Common in the world among marketers is the analysis of consumer behavior depending on their belonging to the generations according to the theory of W. Strauss and N. Howe (Howe \& Strauss, 1992): baby boomers (from the postwar surge in birth rates, approximately 1943-1963 years of birth are collectivists, optimists, educated, poorly adapted to modern technology); X (1963-1984 years of birth are ambitious, responsible, individualists, globally informed, technically literate, value gender equality, stability, but ready for change); Y (1984-2004 years of birth are millennials - energetic, easy to adapt, skeptical, value personal freedom, need quick rewards, strive for new knowledge and development in various fields); Z (since 2004 and later do not imagine life without digital technology, do not like manual labor, irresponsible, not particularly inquisitive, take care of self-expression, have immunity to advertising, because they are accustomed to it since childhood, appreciate the environmental friendliness and usefulness of goods era of commodity diversity, so open to the new, follow fashion).

Millennials, or Generation Y, are people aged 18-35 who are early proponents of technology. They are self-sufficient, travel a lot, plan trips without the help of travel agencies, often combine work and leisure, love personalization, functionality, and want to gain new experience. It is predicted that by 2025 half of all travelers will reach representatives of Generation Y (Soft Industry Alliance, 2019).

From the data in Table 1 we can conclude that the number of millennials in 2020 compared to 1990 decreased by 3,520,035 people, or 26.54\%. Moreover, men decreased by $24.64 \%$, and women were by $28.43 \%$. Among the urban population, the number of millennials decreased in 2020 compared to 1990 by $30.86 \%$, with the largest decrease in women (33.17\%), not men (28.42\%). Among the rural population, generation Y decreased by $15.08 \%$, with women by $14.77 \%$ and men by $10.58 \%$. Thus, there is a general trend to reduce the number of millennials in 2020 compared to 1990, which in the future may negatively affect the hotel and restaurant business and tourism development in Ukraine.

For the successful hotel and restaurant business development it is necessary to take into account the requests of this target audience.

First, millennials are technologically savvy. They actively use gadgets, for example, for booking and order management it is most convenient for them to use mobile applications.

Secondly, in the process of their activity they seek to get an impression. According to a study conducted by Eventbrite, $78 \%$ of people in this demographic group would prefer to spend money on new experiences rather than things. Therefore, small boutique hotels with unusual designs and co working areas are popular.

Today, in exchange for good service, visitors to hotels and restaurants are ready to recommend it for free on social networks. Millennials are ready to share their feedback 
Ресторанний і готельний консалтинг. Інновації. 2021 Том 4 № 1

Restaurant and hotel consulting. Innovations. 2021 Vol. 4 No 1

and suggestions on improving the quality of service on Facebook, Twitter, TripAdvisor, Instagram, TikTok, Telegram, Viber, Booking, Agoda.

Table 1. Millennials in Ukraine in 1990-2020, persons at the beginning of the year

\begin{tabular}{|l|c|c|c|c|c|c|c|c|}
\hline \multirow{2}{*}{ Indicator } & \multicolumn{7}{|c|}{ Year } & \multicolumn{7}{|c|}{$\begin{array}{c}\text { Deviation, } \\
\text { 2020/1990 }\end{array}$} \\
\cline { 2 - 10 } & $\mathbf{1 9 9 0}$ & $\mathbf{2 0 0 0}$ & $\mathbf{2 0 1 0}$ & $\mathbf{2 0 1 8}$ & $\mathbf{2 0 1 9}$ & $\mathbf{2 0 2 0}$ & $+/-$ & $\mathbf{\%}$ \\
\hline $\begin{array}{l}\text { Millennials, } \\
\text { 18-35 years }\end{array}$ & 13260655 & 12221548 & 12682630 & 10442749 & 10127714 & 9740620 & -3520035 & $-26,54$ \\
\hline Men & 6606755 & 6119973 & 6414883 & 5326925 & 5170306 & 4978618 & -1628137 & $-24,64$ \\
\hline Women & 6653900 & 6101575 & 6267747 & 4781720 & 4957408 & 4762002 & -1891898 & $-28,43$ \\
\hline $\begin{array}{l}\text { Urban } \\
\text { population }\end{array}$ & 9636422 & 8595783 & 9110840 & 7261759 & 6986813 & 6662777 & -2973645 & $-30,86$ \\
\hline Men & 4696038 & 4241951 & 4568898 & 3671637 & 3526684 & 3361273 & -1334765 & $-28,42$ \\
\hline Women & 4940384 & 4353832 & 4541942 & 3590122 & 3460129 & 3301504 & -1638880 & $-33,17$ \\
\hline $\begin{array}{l}\text { Rural } \\
\text { population }\end{array}$ & 3624233 & 3625765 & 3571790 & 3180990 & 3140901 & 3077843 & -546390 & $-15,08$ \\
\hline Men & 1808772 & 1878022 & 1845985 & 1655288 & 1643622 & 1617345 & -191427 & $-10,58$ \\
\hline Women & 1713516 & 1747743 & 1725805 & 1525702 & 1497279 & 1460498 & -253018 & $-14,77$ \\
\hline
\end{tabular}

Source: http://database.ukrcensus.gov.ua/Mult/Dialog/varval.asp?ma=000_0204\&path=../ Database/Population/02/02/\&lang=1\&multilang=uk

Maintaining a positive reputation and gaining the commitment of the target audience is achieved in the hotel and restaurant business through effective business communications, quick response to customers' feedback and needs.

A lot of representatives of the hotel and restaurant business are trying to introduce something new, interesting; special that would evoke positive emotions, feelings of joy and happiness. It can be an unforgettable design or exotic services of the institution, which give customers an additional reason to remember them on social networks.

It is possible to improve service in hotel and restaurant business with use of technologies of artificial intelligence. For example, these can be chat bots that answer simple questions, provide recommendations to customers without the participation of staff. Chat bots help you browse menus, place orders, book a table, pay a bill, individual chat bots can recognize human language and answer questions, automatically analyze data and provide more personalized offers to guests according to their preferences.

Internet of Things technology allows conventional devices to receive and receive data using sensors and controllers. Some hotels already use intelligent energy systems based on Internet of Things technology. For example, in smart rooms, the guest can open the door with his smartphone, automatically set the optimal air temperature, lighting and music volume according to preferences. 
Today, millennials are increasingly using technology and do not need contact with people. According to a Gartner study, by 2020, $85 \%$ of consumer interactions took place without human intervention. For example, in hotels of the British chain Yotel the reception is fully automated to register it is enough to enter your data in a special machine and pick up the electronic key from the room. And at Crowne Plaza, a robot named Dash can bring snacks, a toothbrush or other items to a hotel guest (Soft Industry Alliance, 2019).

Internal processes are also subject to automation in the field of accounting, maintenance and control of hotel and restaurant business staff. To do this, CRMsystems are used.

Virtual reality technologies are used in the hotel and restaurant business (VR). It allows you to use interactivity and clarity, which creates a positive impression on customers. In particular, virtual tours are created with the help of VR-technologies. Thanks to them, the future client can see the real digital version of the institution and decide for themselves how to visit it. In parallel, they use augmented reality (AR), which is similar to the previous one, but uses graphic and informational additions. Here you use smartphones and applications through which you can view visitor reviews and opening hours, provide interactive tourist information maps or create interesting content.

On the basis of expert evaluation, a study was conducted among millennials on the feasibility of using the latest technologies in the hotel and restaurant business. To do this, a questionnaire was compiled, which contained 11 questions about innovative technologies that customers would like to use 56 respondents by different age groups were interviewed: 5 people 18 years old, 2 people 19 years old, 3 people 20 years old, 2 people 21 years old, 3 people 22 years old, 4 people 23 years old, 3 people 24 years old, 3 people 25 years old, 4 people 26 years old, 4 people 27 years old, 5 persons 28 years, 2 persons 29 years, 1 person 30 years, 3 persons 31 years, 1 person 32 years, 2 persons 33 years, 5 persons 34 years, 4 persons 35 years.

The distribution of respondents by gender and age groups is given in Fig. 1 .

The survey results are presented in table 2 . According to table 2 we can conclude that the vast majority of millennials prefer to book rooms via smartphones, primarily spend money on impressions, they are impressed by the design and interior of the institution, like exotic dishes and non-standard services, choose a hotel or restaurant that contains a virtual tour and chat maintenance bots prefer unmanned service. Less than 50\% of millennials will spend money on things, provide feedback on hotel and restaurant visits on social networks, will prefer an institution that contains sensors and controllers.

And both men and women will equally use smartphones to book rooms. The vast majority of men will spend money on impressions, provide reviews of hotel and restaurant visits on social networks, prefer exotic dishes, non-standard services and virtual tours, prefer a facility that contains sensors and sensors, unmanned service using chat bots. Millennial women will primarily spend money on things, preferring the design and interior of the institution.

Accordingly, it is necessary to develop a scheme for building a model of the brand, which will be formed by millennials during COVID-19 (Fig. 2). The main elements of the brand model in the hotel and restaurant business should be:

1. Block of goal setting.

2. Block analysis.

3. Audit unit. 
4. Block branding.

5. Block control unit and controlling.

6. Block adjustment and implementation.

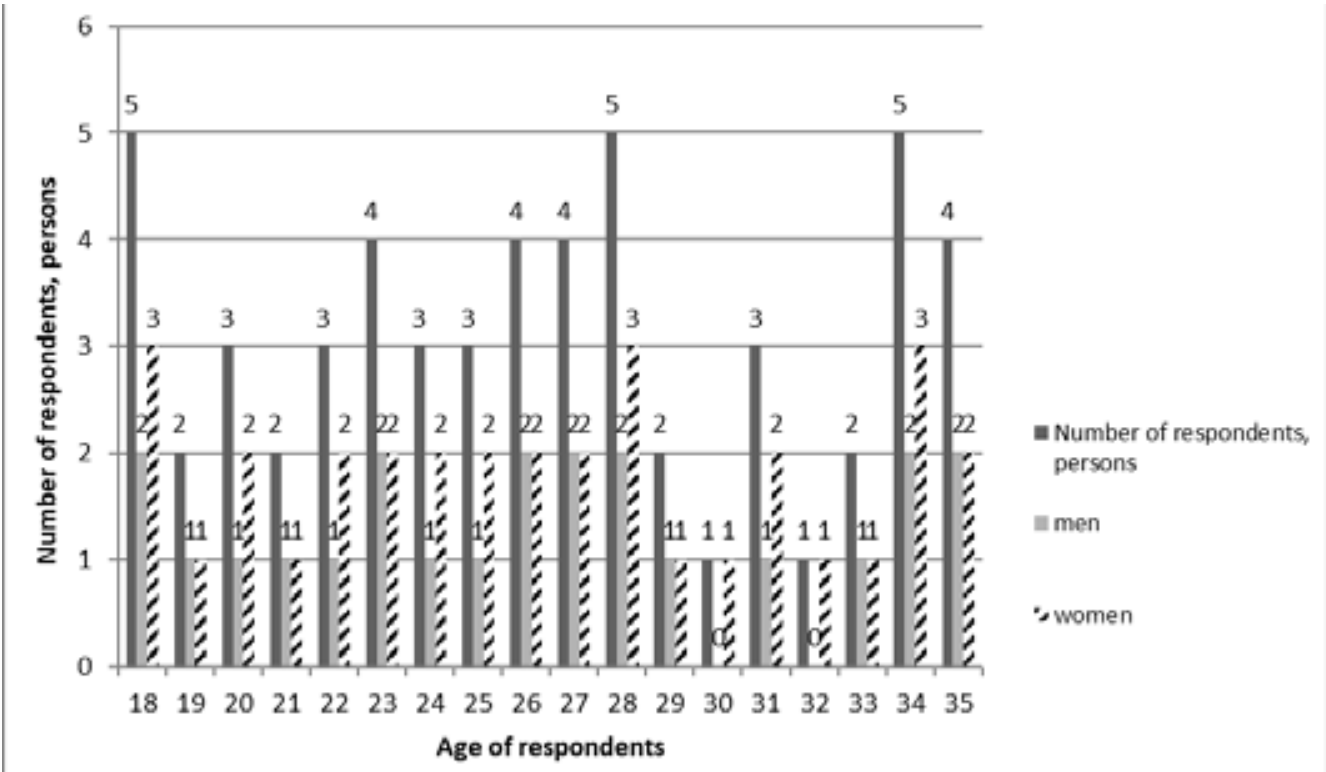

Fig. 1. Distribution of millennial respondents by gender and age groups, persons Source: own development

Table 2. The choice of millennials of the latest technologies in the hotel and restaurant business, people

\begin{tabular}{|l|c|c|c|c|c|}
\hline \multicolumn{1}{|c|}{ The newest technology } & Total & Men & Women & not selected & \% \\
\hline Booking rooms via smartphones & 50 & 25 & 25 & 6 & 89,29 \\
\hline Primarily spend money on impressions & 32 & 18 & 14 & 24 & 57,14 \\
\hline Primarily spend money on things & 10 & 2 & 8 & 46 & 17,86 \\
\hline $\begin{array}{l}\text { Provide reviews for visiting the hotel and } \\
\text { restaurant on social networks }\end{array}$ & 22 & 15 & 7 & 34 & 39,29 \\
\hline $\begin{array}{l}\text { The design and interior of the establishment } \\
\text { is impressive }\end{array}$ & 39 & 18 & 21 & 17 & 69,64 \\
\hline Like exotic dishes & 50 & 29 & 21 & 6 & 89,29 \\
\hline Like non-standard services & 42 & 31 & 11 & 14 & 75,00 \\
\hline $\begin{array}{l}\text { Choose a hotel or restaurant that contains } \\
\text { a virtual tour }\end{array}$ & 30 & 17 & 13 & 26 & 53,57 \\
\hline $\begin{array}{l}\text { Opt for restaurants and hotels, which contain } \\
\text { chat bots maintenance }\end{array}$ & 29 & 18 & 11 & 27 & 51,79 \\
\hline Prefer service without staff & 31 & 19 & 12 & 25 & 55,36 \\
\hline $\begin{array}{l}\text { Prefer an institution that contains sensors } \\
\text { and sensors }\end{array}$ & 19 & 12 & 7 & 37 & 33,93 \\
\hline
\end{tabular}

Source: own development 


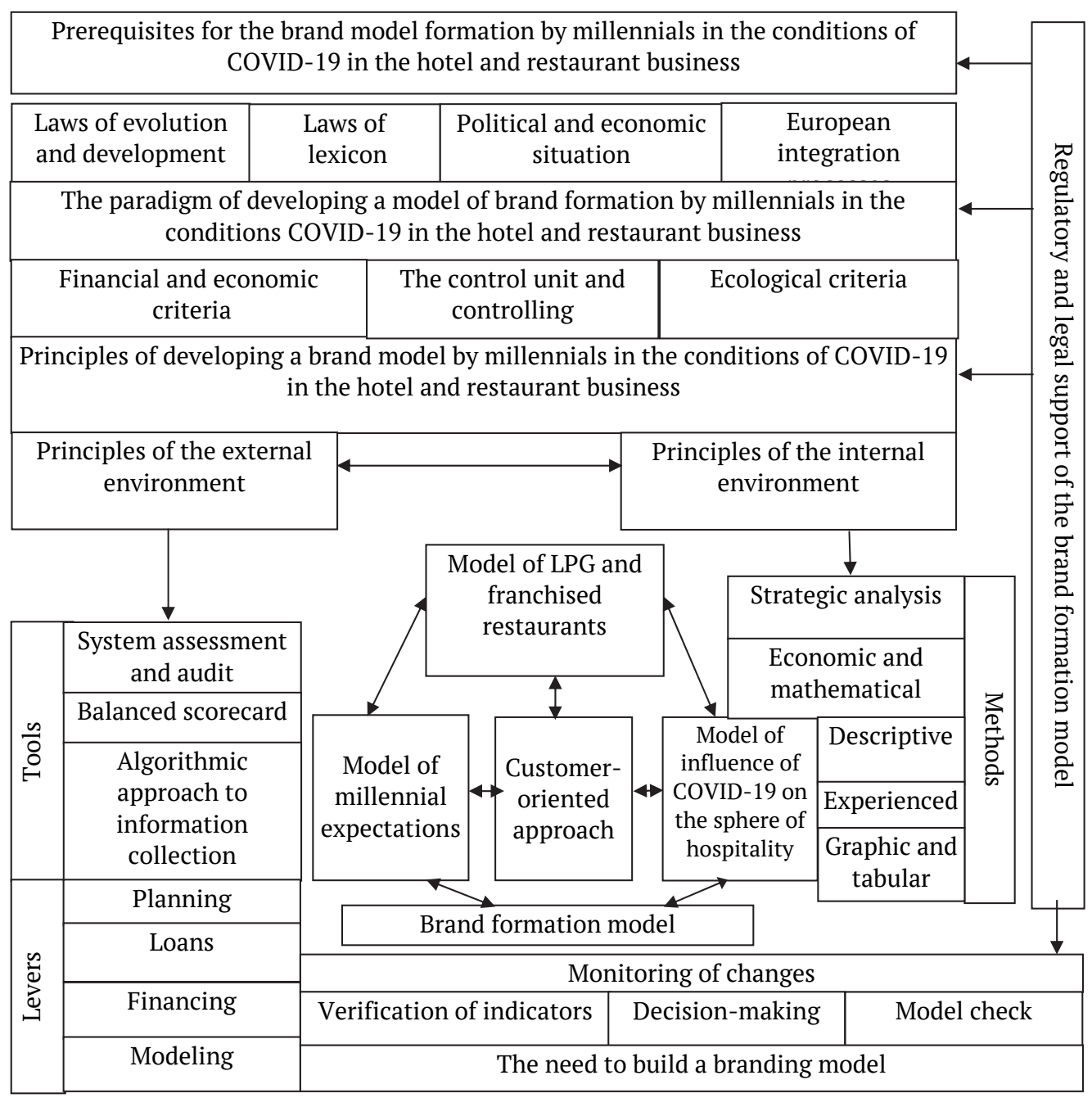

Fig. 2. The scheme of formation of the brand model by millennials in the conditions of COVID-19

Source: own development

The brand model should include a philosophy that should be based on awareness, loyalty to the brand, a positive perception of it by all stakeholders. It is no exception to make a profit, which should be used to develop and improve services in the hotel and restaurant business.

According to experts, work on the image should last at least six months. The scheme of brand formation by millennials is based on a customer-oriented approach, which determines the model of expectations of consumers, LPG and restaurants in 
franchising, the model of the impact of COVID-19 on the hospitality industry and the brand model. Monitoring is a mandatory element of the formation scheme.

\section{Conclusions and results discussion}

The study allowed forming conclusions. It has been established that millennials have a positive impact on the hotel and restaurant business development. They contribute to the formation of a new business philosophy, which is based on the peculiarities of functioning in the conditions of COVID-19. The business philosophy is based on a customer-oriented approach and the use of the latest technologies in all areas of activity. In particular, the use of technology for booking rooms via smartphones and the Internet, the formation of a cult of impressions, not things, expanding communications on social networks, updating the design and interior of the institution, development of exotic dishes, non-standard services, virtual tours, chat bots sensors and controllers.

It is noted that today large hotels need to use the full range of areas of Internet marketing: SEO and content marketing, contextual advertising, PR and social networks, affiliate programs. Budget and mini-hotels will have enough contextual advertising, affiliate programs, as well as, if possible, basic SEO and PR to fill a small fund of rooms.

It is stated that millennials determine the policy of development, stimulate the hotel and restaurant business to constant changes, and lay the foundations for the new technologies development in the field of management, production, service and more. This made it possible to build a scheme of forming a brand model by millennials in the conditions of COVID-19. It lays the preconditions for building a brand model, paradigm and principles of operation, tools, methods, levers, as well as monitoring change processes. It is important to develop a model of the hotel and restaurant business brand, which should be formed under the influence of millennials, LPG and restaurants under the franchise agreement, the impact of COVID-19 on the hospitality industry.

It is noted that millennials are the main driving force of strategic changes in the hotel and restaurant business and contribute to the development and competitiveness of organizations, shape innovation policy, stimulate the new approaches development not only in management but also in other areas, lay the foundations for Industry 4.0. In the future it will be expedient to consider the mechanism of implementation of the scheme of brand model formation by millennials of hotel and restaurant business, to determine the relationships in this model and priority areas of development, taking into account the consequences of pandemic COVID-19, Industry 4.0 and sustainable development economy.

\section{PREFERENCES}

Danylenko, O. V., \& Zotsenko, L. M., \& Bratitsel, M. L. (2019). Priorytety rozvytku tsyfrovykh tekhnolohii $\mathrm{u}$ restorannomu biznesi (FOOODTECH) $\mathrm{v}$ Ukraini [Priorities for the development of digital technologies in the restaurant business (FOOODTECH) in Ukraine]. Scientific notes of Taurida National V.I. Vernadsky University. Series: Economics and Management, 30(69), 2, 95-101 [in Ukrainian]. 
Deloitte. (2020). The Global Millennial Survey. Resilient generations hold the key to creating $a$ „better normal”. https://www2.deloitte.com/ua/uk/pages/press-room/press-release/2020/millenial-survey-2020.html [in English].

Genc, R. (2010). Strategic Brand Management in Hospitality Sector: How to Manage Cobranding in Hotels and Restaurants. Acta universitatis danubius, 3, 33-46 [in English].

Glonti, V., Trynchuk, V., Khovrak, I., Mokhonko, G., Shkrobot, M., \& Manvelidze, L. (2020). Socialization of Organization Sustainable Development Based on the Principles of Corporate Social Responsibility. Montenegrin Journal of Economics, 16(1), 169-182. https://doi.org/10.14254/1800-5845/2020.16-1.11 [in English].

Howe, N., \& Strauss, W. (1992). Generations: The History of America's Future, 1584 to 2069. Quill [in English].

International Monetary Fund. (2020). World Economic Outlook, April 2020: The Great Lockdown. https:/www.imf.org/en/Publications/WEO/Issues/2020/04/14/weo-april-2020 [in English].

Kasum, Z., Bohunovych, B., Durdich-Petrinich, I., \& Hertseh, R. (2020). Pandemiia COVID-19 ta yii naslidky u sferi turyzmu $v$ Ukraini. Onovlennia do dokumentu "dorozhnia karta konkurentospromozhnoho rozvytku sfery turyzmu v Ukraini". [The COVID-19 pandemic and its consequences in the field of tourism in Ukraine. Update to the document "Roadmap for competitive development of tourism in Ukraine"]. http://www.ntoukraine.org/assets/files/ EBRD-COVID19-Report-UKR.pdf [in Ukrainian].

Liashuk, M., \& Yerko, I. (2020). Suchasni tendentsii rozvytku hotelno-restorannoho biznesu rekreatsiinoho raionu [Current trends in the hotel and restaurant business of the recreational area]. Restaurant and hotel consulting. Innovations, 3(1), 109-119. https://doi. org/10.31866/2616-7468.3.1.2020.205574 [in Ukrainian].

Manov, M., \& Karolop, O. (2018). Problemy rozvytku hotelno-restorannoho biznesu v period podolannia kryzy [Problems of development in hotel restaurant business in the period of the current circulation]. Restaurant and hotel consulting. Innovations, 1, 31-40. https:// doi.org/10.31866/2616-7468.1.2018.147405 [in Ukrainian].

Polinkevych, O., \& Kamiński, R. (2018). Corporate image in behavioral marketing of business entities. Innovative Marketing, 14(1), 33-40. https://doi.org/10.21511/im.14(1).2018.04 [in English].

Shatska, Z. Ia., \& Shevel, A. A. (2020). Orhanizatsiia roboty pidpryiemstv hotelnoi sfery v umovakh pandemii COVID-19 [Organization of work of hotel enterprises in the conditions of pandemic COVID-19]. Effective Economics, 10. https://doi.org/10.32702/2307-21052020.10 .51 [in Ukrainian].

Soft Industry Alliance. (2019, September 23). Top-5 trendiv, yaki zminiuiut hotelno-restorannyi biznes [Top 5 trends that change the hotel and restaurant business]. https://soft-industry. com/uk/news/top-5-trendiv-scho-zminuyut-gotelno-restorannyy-biznes [in Ukrainian].

State Statistics Service of Ukraine. (2021). Ekspres vypusky [Express issues]. http://www.ukrstat. gov.ua/ [in Ukrainian].

Trishkina, N. I. (2017). Formuvannia systemy brend-oriientovanykh intehrovanykh marketynhovykh komunikatsii pidpryiemstv hotelnoho hospodarstva [Formation of a system of brand-oriented integrated marketing communications of hotel enterprises]. Market Infrastructure, 13, 197-202 [in Ukrainian].

Verevka, T. V. (2019). Development of Industry 4.0 in the Hotel and Restaurant Business. IBIMA Business Review, Vol. 2019, Article ID 324071. https://doi.org/10.5171/2019.324071 [in English].

Zubarieva, M. A. (2015). Instrumenty populiaryzatsii hoteliu u sotsialnykh merezhakh [Tools to promote the hotel on social networks]. Global and National Economic Problems, 4, 738-742 [in Ukrainian]. 
УДК 640.4:659.126]:316.346.32-053.81”18/35”

Оксана Полінкевич,

докторка економічних наук,

Луцький національний технічний університет,

м. Луцьк, Україна,

kravomp@gmail.com

https://orcid.org/0000-0001-6924-7296

\section{РОЛЬ МІЛЕНІАЛІВ У ФОРМУВАННІ БРЕНДА ГОТЕЛЬНО-РЕСТОРАННОГО БІЗНЕСУ}

Актуальність. В умовах пандемії COVID-19 важливе значення набувають новітні технології стимулювання розвитку бізнесу. Джерелом змін $є$ міленіали, які визначають перспективи розвитку та сприяють формуванню конкурентоспроможності на ринку. Мета статті - визначення ролі міленіалів у формуванні бренда готельно-ресторанного бізнесу в умовах COVID-19. Методи дослідження. При проведенні дослідження використовувались загальнонаукові методи: аналізу, абстракції, індукції, дедукції, синтезу, умовиводу, узагальнення, порівняння. Результати дослідження. Визначено особливості поняття «міленіали». Встановлено, що міленіали - це молоді люди віком 18-35 років, які позитивно впливають на розвиток готельно-ресторанного бізнесу та $є$ генераторами змін. Проведено експертне оцінювання впливу міленіалів на готельно-ресторанний бізнес. У ньому визначено основні технології, яким віддають перевагу міленіали за статтю та віковою групою. Розроблено схему формування моделі бренда міленіалами в умовах COVID-19. Висновки та обговорення. Визначено, що міленіали є основною рушійною силою стратегічних змін у готельно-ресторанному бізнесі та сприяють розвитку і конкурентоспроможності організацій.

Ключові слова: готельно-ресторанний бізнес, міленіали, COVID-19, схема, розвиток, бренд, брендинг. 
Актуальні проблеми розвитку готельно-ресторанного бізнесу Actual problems of the hotel and restaurant business development

УДК 640.4:659.126]:316.346.32-053.81”18/35”

\author{
Оксана Полинкевич, \\ доктор экономических наук, \\ Луцикий нацииональный технический университет, \\ 2. Луцк, Украина, \\ kravomp@gmail.com \\ https://orcid.org/0000-0001-6924-7296
}

\title{
РОЛЬ МИЛЕНИАЛОВ В ФОРМИРОВАНИИ БРЕНДА ГОСТИНИЧНО-РЕСТОРАННОГО БИЗНЕСА
}

Актуальность. В условиях пандемии COVID-19 важное значение приобретают новейшие технологии стимулирования развития бизнеса. Источником изменений являются милениалы, которые определяют перспективы развития и способствуют формированию конкурентоспособности на рынке. Цель статьи - определение роли милениалов в формировании бренда гостинично-ресторанного бизнеса в условиях COVID-19. Методы исследования. При проведении исследования использовались общенаучные методы: анализа, абстракции, индукции, дедукции, синтеза, умозаключения, обобщение, сравнение. Результаты исследования. Определены особенности понятия «милениалы». Установлено, что милениалы - это молодые люди в возрасте 18-35 лет, которые положительно влияют на развитие гостинично-ресторанного бизнеса и являются генераторами изменений. Проведено экспертное оценивание влияния милениалов в гостинично-ресторанном бизнесе. В нем определены основные технологии, которые предпочитают милениалы по полу и возрастной группе. Разработана схема формирования модели бренда милениалами в условиях COVID-19. Выводы и обсуждение. Определено, что милениалы являются основной движущей силой стратегических изменений в гостинично-ресторанном бизнесе и способствуют развитию и конкурентоспособности организаций.

Ключевые слова: гостинично-ресторанный бизнес, милениалы, COVID-19, схема, развитие, бренд, брендинг. 